Preprint

UCRL-JC-135347

\title{
Stiffness and Strength Properties for Basic Sandwich Material Core Types
}

B. Kim, R.M. Christensen

This article was submitted to

ASME IMECE '99, Nashville, TN, November 14-19, 1999

\section{August 3, 1999}

U.S. Department of Energy

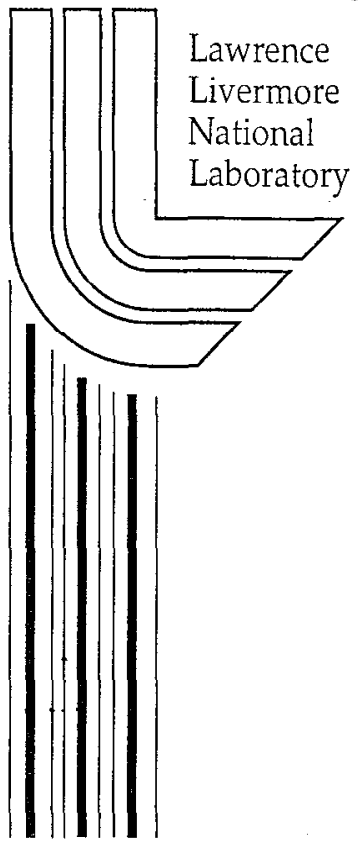




\section{DISCLAIMER}

This document was prepared as an account of work sponsored by an agency of the United States Government. Neither the United States Government nor the University of California nor any of their employees, makes any warranty, express or implied, or assumes any legal liability or responsibility for the accuracy, completeness, or usefulness of any information, apparatus, product, or process disclosed, or represents that its use would not infringe privately owned rights. Reference herein to any specific commercial product, process, or service by trade name, trademark, manufacturer, or otherwise, does not necessarily constitute or imply its endorsement, recommendation, or favoring by the United States Government or the University of California. The views and opinions of authors expressed herein do not necessarily state or reflect those of the United States Government or the University of California, and shall not be used for advertising or product endorsement purposes.

This is a preprint of a paper intended for publication in a journal or proceedings. Since changes may be made before publication, this preprint is made available with the understanding that it will not be cited or reproduced without the permission of the author.

This report has been reproduced directly from the best available copy.

Available to DOE and DOE contractors from the

Office of Scientific and Technical Information

P.O. Box 62, Oak Ridge, TN 37831

Prices available from (423) 576-8401

http://apollo.osti.gov/bridge/

Available to the public from the

National Technical Information Service

U.S. Department of Commerce 5285 Port Royal Rd., Springfield, VA 22161 http://www.ntis.gov/

OR

Lawrence Livermore National Laboratory Technical Information Department's Digital Library http://www.llnl.gov/tid/Library.html 


\title{
STIFFNESS AND STRENGTH PROPERTIES FOR BASIC SANDWICH MATERIAL CORE TYPES
}

\author{
Beomkeun Kim* \\ Stanford University \\ Stanford, Callfornia, 94305 United States \\ Richard M. Christensen \\ Lawrence Livermore National Laboratory, P. O. Box 808 \\ Livermore, California 94551 , United States \\ Phone: (925) 422-7136, Fax: (925) 423-2405 \\ christensen6@IInl.gov
}

\begin{abstract}
Three basic core material types for sandwich structure applications are studied. The three twodimensional pattern types are: honeycomb, triangular cells, and a new configuration involving star type cells. The specific critical properties of stiffness and strength type are identified and studied, both theoretically and experimentally.
\end{abstract}

\section{INTRODUCTION}

Sandwich structures have been used in numerous aspects of aircraft construction as well as in many other applications. Typical sandwich structures are made up of two thin, stiff, strong faces separated by a very lightweight material known as the core. By choosing appropriate core materials based on intended applications, not only are sandwich panels able to achieve high stiffness, and strengths comparable to those of single solid panels, but also great savings in weight.

Many types of low density materials that satisfy the requirements of sandwich structures are used as core materials, and one of the most popular cores is the hexagonal core. This core has a twodimensional hexagonal pattern made of thin walled structures in one plane. Because cores with twodimensional patterns such as hexagonal core provide a direct connection between the face panels, they generally show good structural efficiency.
When a material has hexagonal symmetry like a hexagonal core (Figure 1), the stiffness matrix relating stresses and strains has five independent constants. This reveals that the hexagonal core can be considered transversely isotropic and has a plane of isotropy. Gibson and Ashby [1997] have extensively studied the honeycomb form.

A core with a triangular pattern is also isotropic in the plane. One triangle shows only triangular symmetry. However, if six triangles are combined, this pattern has hexagonal symmetry as shown in Figure 1 . in other words, this triangular core is isotropic in this plane. Christensen [1995] suggested a new two-dimensional pattern which has sixpointed star-shaped cells adjacent to hexagonal cells. This pattern also has hexagonal symmetry and is isotropic in the plane (Figure 1).

In the current study, the primary objective is to examine and compare the relevant mechanical characteristics of behavior for the three core types having isotropic patternsthe triangular core, the hexagonal core and the starcell core-as related to applications in sandwich structures. 


\section{Results}

The mechanical characteristics of three types of cores with two-dimensional isotropic patternstriangular, hexagonal, and starcell-were studied as related to applications in sandwich structures. The Young's modulus, shear modulus, and Poisson's ratio were calculated for the three core types in the direction normal to the faces. The compressive buckling strength and shear buckling strength were calculated for the three core types by modeling each cell wall of the core as a plate under compressive or shear load. To verify this model, tests were conducted on scaled specimens to measure the compressive buckling strength of each core. The bending flexibility's of the three cores were also studied. Compliances for the three cores were measured using flexural tests. Tests were performed on each core type in which the deflection of a circular core sample loaded at its center was measured. The three isotropic core patterns exhibited distinct characteristics, as shown in Figure 2. The results are expressed as a function of the relative density of the core material, and discussed in more detail by Kim and Christensen [1999].

\section{REFERENCES}

Gibson, L. J. and Ashby, M., Cellular Solids Structure and Properties (Cambridge University Press, Cambridge, 1997).

Christensen, R. M., "The hierarchy of microstructures for low density materials," ZAMP 46 (1995) 5506-5521.

Kim, B. and Christensen, R. M., "Basic TwoDimensional Core Types for Sandwich Structures," Int. J. Mechanical Sciences, in press.

This work was performed under the auspices of the U.S. Department of Energy by Lawrence Livermore National Laboratory under contract No. W-7405-Eng-48. 
- Objective

Detailed study of three prototype 2-D core forms for sandwich structures

- Basic 2-D Core Forms

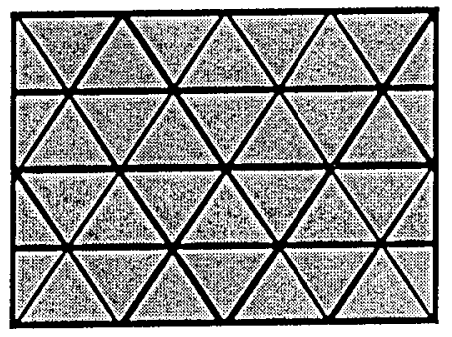

Triangular

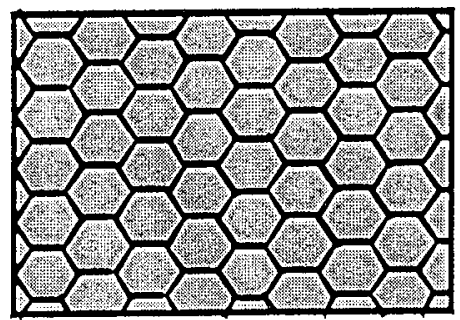

Hexagonal (Honeycomb)
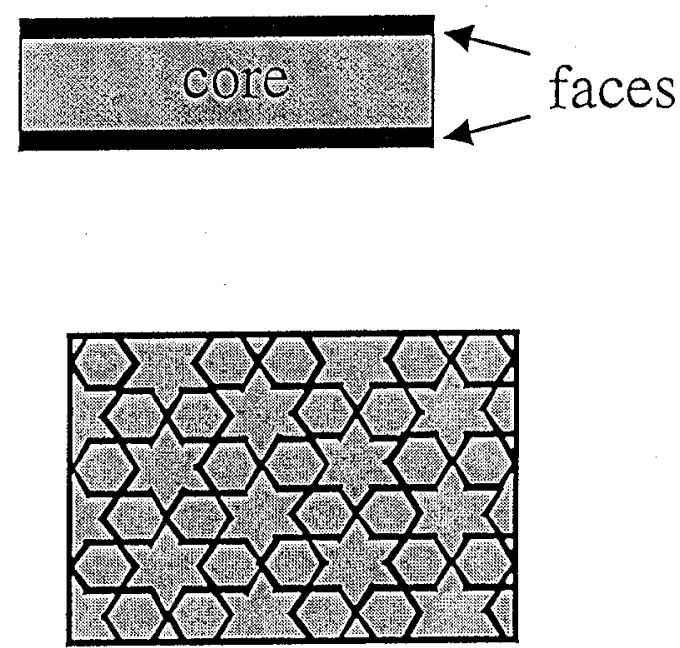

Star

(New Form)

- Approach Theoretical and Experimental investigation of three dimensional stiffness and strength properties

- Critical Properties In-plane moduli, shear $\mathrm{G}$ and bulk $\mathrm{K}$ Out of plane shear strength 
$\underline{\text { Stiffness }}$

Theory

$$
\begin{array}{llll} 
& \text { Triangular } & \text { Hexagonal } & \text { Star } \\
\mathrm{G} / \mathrm{E}_{\mathrm{m}} & \frac{1}{8}\left(\frac{\rho}{\rho_{\mathrm{m}}}\right) & \frac{3}{8}\left(\frac{\rho}{\rho_{\mathrm{m}}}\right)^{3} & \frac{3}{16}\left(\frac{\rho}{\rho_{\mathrm{m}}}\right)^{3} \\
\mathrm{~K} / \mathrm{E}_{\mathrm{m}} & \frac{1}{4}\left(\frac{\rho}{\rho_{\mathrm{m}}}\right) & \frac{1}{4}\left(\frac{\rho}{\rho_{\mathrm{m}}}\right) & \frac{\rho}{16}\left(\frac{\rho}{\rho_{\mathrm{In}}}\right)^{3} \\
* \rho \text { - density } &
\end{array}
$$

Compressive Strength, Shear Strength Theory

Triangular Hexagonal \& Star

$\sigma_{\mathrm{cr}} \quad \frac{1}{9} \beta_{\mathrm{n}} \frac{\mathrm{E}_{\mathrm{m}}}{1-v_{\mathrm{m}}^{2}}\left(\frac{\rho}{\rho_{\mathrm{m}}}\right)^{3} \beta_{\mathrm{n}} \frac{\mathrm{E}_{\mathrm{m}}}{1-v_{\mathrm{m}}^{2}}\left(\frac{\rho}{\rho_{\mathrm{m}}}\right)^{3}$

$\tau_{\mathrm{cr}} \quad \frac{1}{9} \beta_{\mathrm{s}} \frac{\mathrm{E}_{\mathrm{m}}}{1-v_{\mathrm{m}}^{2}}\left(\frac{\rho}{\rho_{\mathrm{m}}}\right)^{3} \quad \beta_{\mathrm{s}} \frac{\mathrm{E}_{\mathrm{m}}}{1-v_{\mathrm{m}}^{2}}\left(\frac{\rho}{\rho_{\mathrm{m}}}\right)^{3}$

$* \beta_{\mathrm{n}}, \beta_{\mathrm{s}}$ from boundary conditions
Stiffness

Experiment

Compliance(inches/lbs)

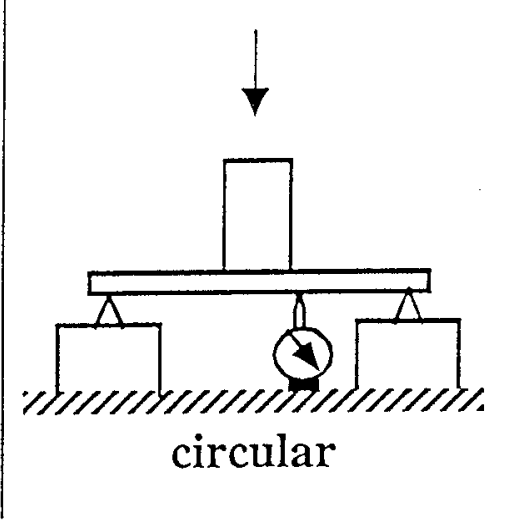

Strength

Experiment

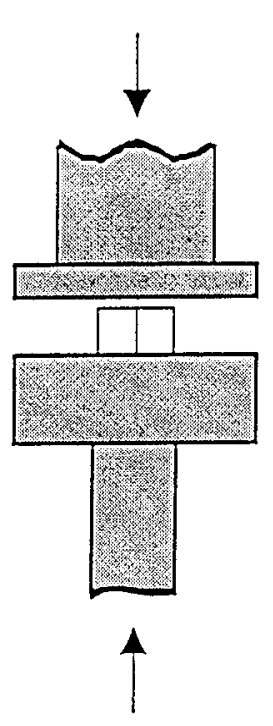

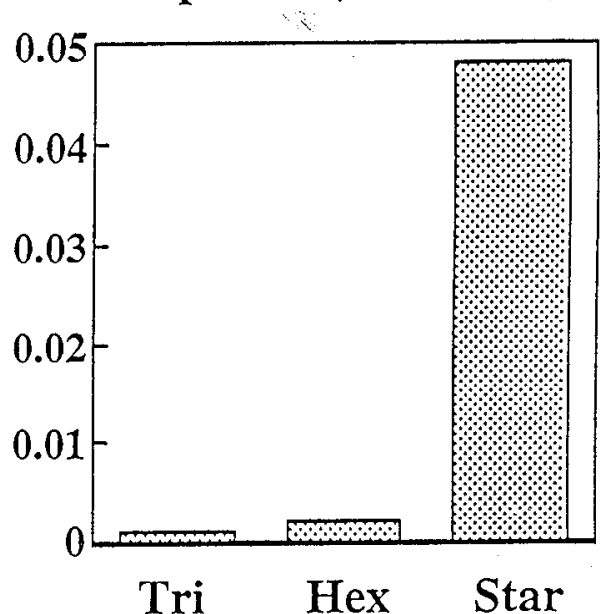

$\sigma_{\mathrm{cr}}\left(\frac{\rho}{\rho_{\mathrm{m}}}\right)^{3}(\mathrm{Msi})$

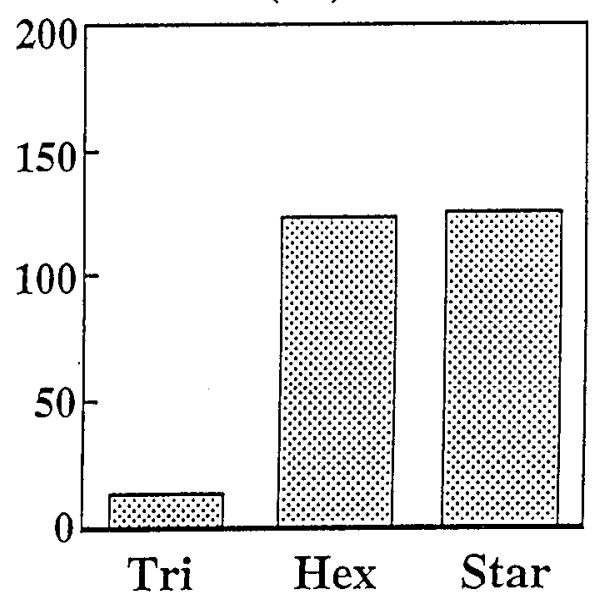

Figure 2 Results 